\title{
Market Integration of Agricultural Products
}

\author{
Taufiq Marwa ${ }^{1}$, Abdul Bashir ${ }^{2}$, Azwardi $^{3}$, Mohamad Adam $^{4}$, K.M.H. \\ Thamrin $^{5}$
}

\begin{abstract}
:
The study aims to investigate the relationship between the prices of agricultural products at the producer level with the prices of the same products at the consumer level in South Sumatera, Indonesia with a case study on the production and consumption of rice as the most important agricultural product in Indonesia.

The analytical approach is linear regression modelling with Ordinary Least Squares (OLS), and the Approach of Index Market Connection model (IMC).

The findings of the study indicated integration between the price of rice at the producer level and the price of rice at the consumer level. In addition, the three sample regions have IMC value less than 1, meaning that both markets have vertical integration in the short run.

Another finding of this study is that the high price difference at the local market level is due to the long distribution of rice commodities in South Sumatera. Government intervention is particularly needed at the local market-level on pricing policy by shortening the distribution channels.
\end{abstract}

Keywords: Market, integration, distribution, production, consumption.

JEL Classification: D3, F15, Q11, Q13, Q52.

\footnotetext{
${ }^{1}$ Department of Development Economic, Sriwijaya University, taufiqmarwa@unsri.ac.id

${ }^{2}$ Department of Development Economic, Sriwijaya University, abd.bashir@unsri.ac.id

${ }^{3}$ Department of Development Economic, Sriwijaya University, azwardi_unsri@yahoo.com

${ }^{4}$ Department of Management, Sriwijaya University, Indonesia,mr_adam2406@yahoo.com

${ }^{5}$ Department of Management, Sriwijaya University, Indonesia, kemasmhthamrin@gmail.com
} 


\section{Introduction}

Agricultural policy in Indonesia has been focusing on the increase of rice production to achieve and sustain self-sufficiency in rice, while on the other side, the government implements 'cheap rice' policy, which causes problems. As a result of this policy, there are some problems such as: (1) farmers are less enthusiastic to produce, (2) consumers are very dependent on rice (Taufiq, 2001).

The problem of the rice price is significant since the economic crisis in 1998. On $1^{\text {st }}$ of June 1998, government set the price of unhulled rice as Rp. 1000 per kilogram while the price at wholesale level has reached Rp. 1850 per kilogram. Since then, the price disparities of unhulled rice and rice have continued to be one of the complex issues for the Indonesian government (Arifin et al., 2006).

In addition, one of the causes of the asymmetric price transmission between vertically linked markets is the existence of uncompetitive behavior among intermediate traders, especially if the intermediary trader is in a concentrated market (Vavra and Goodwin, 2005; Epifanova et al., 2015; Kovalenko et al., 2016). In general, the intermediary trader will try to maintain the profit level and will not raise/lower the price according to the actual price signal. So the intermediary trader will react faster to the price increase compared to the price decline. This condition causes competition restraint on the distribution line and the imperfect price transmission between producer and consumer. At the end the farmers' and the consumers' markets become unintegrated.

Similarly, the uncompetitive market causes the inexistence of price transmission between two different market levels in the marketing chain. Especially for agricultural commodity, the imperfect competition in marketing chain opens opportunity for the middleman to abuse the market power (Meyer and CramonTaubadel, 2004).

The view of mainstream economics explains that the concept of the market is the existence of consumer and producer to interact in exchanging products, services, and information. In addition, the market is a complex institution that shapes hierarchy and interrelationships in the transaction involving various commodities simultaneously (Palaskas and Harris, 1993). There are two roles of a market; firstly, it facilitates trade and allows the distribution and allocation of resources in the community; secondly, it allows all products and services to be evaluated and priced (Taufiq, 2001). Furthermore, the performance of the rice market can be established through market integration (Chizari et al., 2013; Azwardi et al., 2016). One of the determinants of price is the distribution chain of the products and services itself. This gives an impact on the price differences in two different locations leading to an integrated market between locations (Adam et al., 2017). Similarly, Taufiq (2001) states that market integration could also happen in the different market that correlated with one another. 
The behavior of the price in local rice market is an important indicator of the whole market performance, and the unintegrated market could deliver inaccurate information, distort producers' marketing decision and give inefficient product distribution (Chizari et al., 2013; Azwardi et al., 2016). Therefore, this study focuses on the analysis of market integration, which is the analysis of the regional and central price of rice in South Sumatera.

In this study, we try to find and investigate the market integration of rice by looking at the behavior of prices in the local market. The study has differences compared to other studies conducted by Edi et al. (2014), Nuraeni et al. (2016) Agung and Daryanto (2017) because of the following: first, it gives input for the government to improve the policy of price determination to achieve market equilibrium; second, it extends the literature related to a theoretical aspect of the market integration and the determination of the price of rice at producer and consumer levels.

\section{Literature Review}

Generally, there are three types of markets, namely: (1) geographical based market, (2) product-based market and (3) time period-based market. Geographical based market consists of local market, regional market, national market and international market; product-based market refers to those markets that are distinguished by the products sold. Time period-based markets are those that are categorized on their availability on time (Taufiq, 2001). Geographical based market is the type of agricultural commodity market that is often analysed, such as the productioncentered market, the retail or local market and the central market. The movement of agricultural commodities from the production center market to the retail market or from the local market to the central market usually faces several constraints, including distance problems and other infrastructure constraints. As a result of these constraints, differences in prices arise in each of these markets (Emokaro, 2014; Taufiq, 2001; Breckova, 2016; Bondarenko et al., 2017).

The market has price integration from one another, which causes by producers and consumers communicating through price signals. Therefore, price is a communication signal that serve variations to coordinate market decisions in which, supply and demand determines the market price. If inter-market is related to supply and demand, the price between the market, will also be integrated (Leonard, 2011; Emokaro, 2014; Taufiq, 2001). The type of market based on geography can be seen by the price differences between the market which is caused by transportation cost. Such situation could happen if, firstly, both seller and buyer cannot control the price by withholding the supply and demand; secondly, the products traded are homogenous; thirdly, there is no barriers of entry and, lastly, seller and buyer have perfect information on costs and prices (Chizari et al., 2013; Taufiq, 2001). The precondition for the above-mentioned market integration is to have a perfect competitive market structure. Therefore, market structure analysis is one of the ways 
to determine whether there is a perfect and efficient market integration (Taufiq, 2001).

Market integration is one of the indicators of marketing efficiency especially price efficiency. In addition, the market integration is one of the indicators that measures the price deviation from the refered market (a market at a higher level such as retailers) leading to the changes in the next market (e.g. farmers market). Therefore, the analysis of market integration is closely related with market structure (Taufiq, 2001). Furthermore, Fadhla et al. (2008) and Asmarantaka (2009) explains that a market is integrated if the change in price in one of the markets (primary market) is transferred to the other market (secondary market). In perfect competition, a price change in the primary market is perfectly transferred to the farmer (secondary market). Market integration will be established if there is enough information and these information is transferred rapidly to the other market leading the two markets (primary and secondary) the same information.

The factors that effect market integration are: (1) market inftastructure, such as: transportation, communication, credit and other saving facilities in the market; (2) government policy that affects marketing system, such as: trade tightening, credit and transportation regulation; (3) imbalances of inter-regional production resulting in market surplus (exporting only to other market) and deficit market (importing only to other markets); (4) a supply shock such as flood, draught and illness that will affect production scarcity because of allocation defficiencies while other unexpected events such as strikes will complicate the commodity transfer (Goletti et al., 1994).

A recent study, by Sanogo and Maliki (2010), implements autoregressive model on the integration of the rice market in Nepal and India. The results show that the adjustment of negative price deviations from long-term stable equilibrium is faster than a positive deviation adjustment. Furthermore, Kariuki (2011) uses different model in his study in analyzing the performance of fish market in Kenya. Kariuki (2011) uses co-integrated model to check the relationship of prices in different locations. Ajjan et al. (2013) studies the market integration of the peas market in India and concluded that market has a price relationship and therefore an integrated one.

Paul et al. (2015) studies export volatility, structural price and the relationship betwee domestic prices and export of red onion in India, in which, co-integrated models and Granger causality tests are used. The results show that prices in all market shares are stable in the long-term. The result of Granger test shows consistency in all main domestic markets of red onions causing export price to move in one direction. Furthermore, Wani et al. (2015) in their study on market integration and the estimation of apple price in India, uses a co-integrated analysis to determine the level of market integration. The results show that the selected apple market is very integrated and focus on long-term equilibrium. 


\section{Research Method}

This study is conducted in three rice producing areas in South Sumatera namely, Banyuasin, Ogan Komering Ilir (OKI) and Ogan Komering Ulu Timur (OKUT). The analysis of the level of market integration is done through three stages: the first stage is to see the market network using a rapid marketing appraisal. The second stage is to see the level of market integration using time series analysis. The third stage is to outline the factors that affect the level of market integration. The basic information that is collected on market networking, such as (a) the number and type of participants in every market and the transaction volume on each market, (b) channel or trade flows between different markets, (c) infrastructure access through the market, (d) the level of price information from each participant, and (e) the level of information related to government program.

The level of market integration is measured through several ways, such as (1) Granger causality model; (2) linear regression model; (3) co-integration model; (4) dynamics adjustment model; (5) dynamic multiplier model; (6) Timmer's index of market connection coefficient. This study uses the linear regression model and Timmer's index of market connection in measuring the market integration.

\subsection{Model of Linear Regression}

Market integration is measured using regression analysis with the following equation:

$$
\mathrm{Pf}_{\mathrm{jt}}=\mathrm{a}_{0}+\mathrm{b}_{1} \mathrm{Pr}_{\mathrm{jt}}+\mathrm{U}_{\mathrm{i}}
$$

In which: $\mathbf{P} \mathbf{f}_{\mathbf{i t}}$ is the price at the level of seller/producer $\mathrm{i}$ at the period of $\mathrm{t} ; \mathbf{P r}_{\mathbf{j t}}$ is the price at consumer level $\mathbf{j}$ at the period of $\mathbf{t} ; \mathbf{a}_{\mathbf{0}}$ is constant; $\mathbf{a}_{\mathbf{1}}$ is parameter; and $\mathbf{U}_{\mathbf{i}}$ is error-term.

With reference to Monke and Petzel (1984) criteria in Taufiq (2001), if two markets are independent to one another, the price movement in each market will be random or unrelated on one another, therefore, it can be said that the markets are not integrated. This is indicated by the $\mathbf{b}$ coefficient being not significantly different from zero. Conversely, if the $\mathrm{b}$ coefficient is significantly different from zero, this shows interdependence between the prices that are being analysed. This also indicates that, at a particular point, there is market integration. Details of the relationship can be seen in Table 1 .

Table 1. The level of market integration based on regression analysis

\begin{tabular}{cccl}
\hline No & Coefficient Value & Price Relationship & \multicolumn{1}{c}{ Integration Level } \\
\hline 1 & $\mathrm{a}=0, \mathrm{~b}=0$ & Independent & Not integrated \\
2 & $\mathrm{a} \neq 0, \mathrm{~b}=0$ & Independent & Not integrated
\end{tabular}




\begin{tabular}{llll}
3 & $a=0, b>0 \& b=1$ & Identical & Integrated \\
4 & $a=0, b>0 \& b \neq 1$ & Pure percentage premium & Integrated \\
5 & $a \neq 0, b>0 \& b=1$ & Absolute premium & Possibly integrated \\
6 & $a \neq 0, b>0 \& b \neq 1$ & Pure Perc.\& abs.premium & Possible integrated \\
\hline
\end{tabular}

Source: Monke, E. and T. Petzel (1984).

\subsection{Model of the Index of Market Connection Cofficient}

This index is developed by Timmer (1987) to measure market long-term and shortterm market integration. This method concludes that market structure is consisting of one primary market and several secondary markets. Primary market controls price determination while secondary markets respond the condition of primary market. This approach has also been used by Oladapo and Momoh (2007) and adopted by Adeoye et al. (2011) and Akintunde et al. (2012).

To calculate Timmer's index of market connection coefficient or index of market connection (IMC), the following equation is used (Heytens, 1986; Timmer, 1987).

$$
\begin{gathered}
\mathrm{Pf}_{\mathrm{t}}=\mathrm{a}+(1+\mathrm{b}) \mathrm{Pf}_{\mathrm{t}-1}+\mathrm{c}\left(\mathrm{Pr}_{\mathrm{t}}-\mathrm{Pr}_{\mathrm{t}-1}\right)+(\mathrm{d}-\mathrm{b}) \mathrm{Pr}_{\mathrm{t}-1}+\mathrm{eX}_{\mathrm{t}-1} \\
+\mathrm{U}_{\mathrm{t}}
\end{gathered}
$$

In which: $\mathbf{P} \mathbf{f}_{\mathbf{t}}$ is the price at secondary market (farmer); $\mathbf{P r}_{\mathbf{t}}$ is the $\log$ of primary market (lead=consumer level); $\mathbf{X}$ is seasonal factor or other factors; and $\mathbf{t}$ refers to the period. To facilitate the estimation of parameter coefficient, equation (2) is transformed into:

$$
\begin{gathered}
\mathrm{Pf}_{\mathrm{t}}=\beta_{0}+\beta_{1} \mathrm{Pf}_{\mathrm{t}-1}+\beta_{2}\left(\mathrm{Pr}_{\mathrm{t}}-\mathrm{Pr}_{\mathrm{t}-1}\right)+\beta_{3} \mathrm{Pr}_{\mathrm{t}-1}+\beta_{4} \mathrm{X}_{\mathrm{t}-1} \\
+\mu_{\mathrm{t}}
\end{gathered}
$$

In which: $\boldsymbol{\beta}_{\mathbf{1}}$ is the parameter of $(\mathbf{1}+\mathbf{b}) ; \boldsymbol{\beta}_{\mathbf{2}}$ is the parameter of $\mathbf{c} ; \boldsymbol{\beta}_{\mathbf{3}}$ is the parameter of $(\mathbf{d}-\mathbf{b})$; and $\boldsymbol{\beta}_{\mathbf{4}}$ is the parameter of $\mathbf{e}$.

Index of market connection (IMC) can be calculated using the following equation:

IMC

$=\frac{(1+b)}{(d-b)}$

Since $\boldsymbol{\beta}_{\mathbf{1}}=\mathbf{1}+\mathbf{b}$, and $\boldsymbol{\beta}_{\mathbf{3}}=(\mathbf{d}-\mathbf{b})$, thus, equation (5) is:

IMC

$=\frac{\beta_{1}}{\beta_{3}}$ 
Index of market connection is an index that is limited as the ratio of the previous market's secondary market coefficient $(\mathrm{t}-1)$ to the primary market (reference) of the previous period (Heytens, 1986; Timmer, 1987). The market is integrated in shortterm if $\boldsymbol{\beta}=\mathbf{- 1}$, and $\mathbf{I M C}=\mathbf{0}$. If the market is not integrated in the short-term the value of $\mathrm{IMC}=\infty$ (the value of $\mathrm{d}$ and $\mathrm{b}$ are the same). If $\mathbf{I M C}<\mathbf{1}$, the can said that primary market has a strong relationsip, conversely, if $\mathbf{I M C}>\mathbf{1}$, it indicates that primary market does not exist. Long-term integration is shown by coefficient $\mathbf{c}\left(\boldsymbol{\beta}_{2}\right)$, if $\mathbf{c}\left(\boldsymbol{\beta}_{2}\right)$ is equal to $\mathbf{1}$ (the price in primary market is transmitted proportionally to secondary market).

\section{Results and Discussion}

\subsection{Production and Consumption of Rice Food}

The development of rice production is affected by weather, land area as well as the area that rice can be planted. Currently, the production development is also determined by seeds and fertilizers used by the farmers. Indonesia is still experiencing a food crisis for rice; it is evident that the Indonesian government is still importing to cover the rice consumption deficit.

South Sumatera is the 6th biggest rice producer in Indonesia and the second in Sumatera Island after North Sumatera. However, the government need to pay more attention on the production development as it decreases, which caused by conversion of agricultural land to plantation such as rubber and palm oil. Therefore, agricultural land is getting less and smaller. The development of rice has shown a positive trend. It can be seen by the average growth of rice production from 1990-2014 that has been increasing up to $4.91 \%$, while the rice consumption is increasing by $1.06 \%$. In the case of South Sumatera, the rice production is more than the consumption, which can be said that there is a surplus. Rice surplus in South Sumatera is on line with the program of South Sumatera government to be national food granary. Rice surplus in South Sumatera in the last six years has become good news, in which there is more than 1 million tonnes of rice surplus on average.

Figure 1. Rice production and consumption in South Sumatera

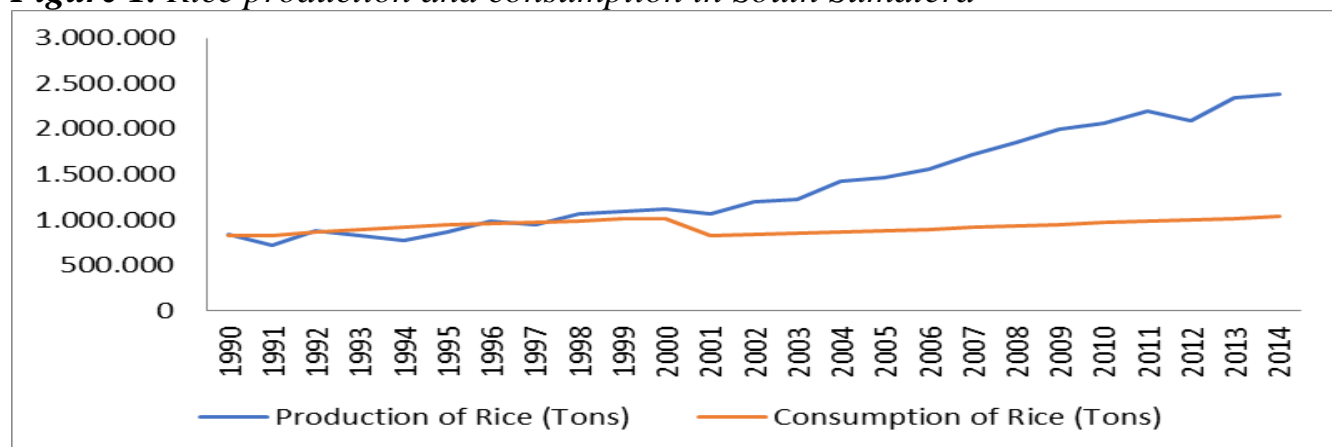

Source: Central Bureau of Statistics (BPS), South Sumatera in figures, 2016 
The condition of rice surplus in South Sumatera is marked with the increase in farmer's productivity each year. Figure 2 shows the development of rice productivity per quintal per hectare. In the beginning of 1993, farmer productivity is 32.04 and has increased up to 46.67 in 2015.

Figure 2. Productivity of rice production in South Sumatera

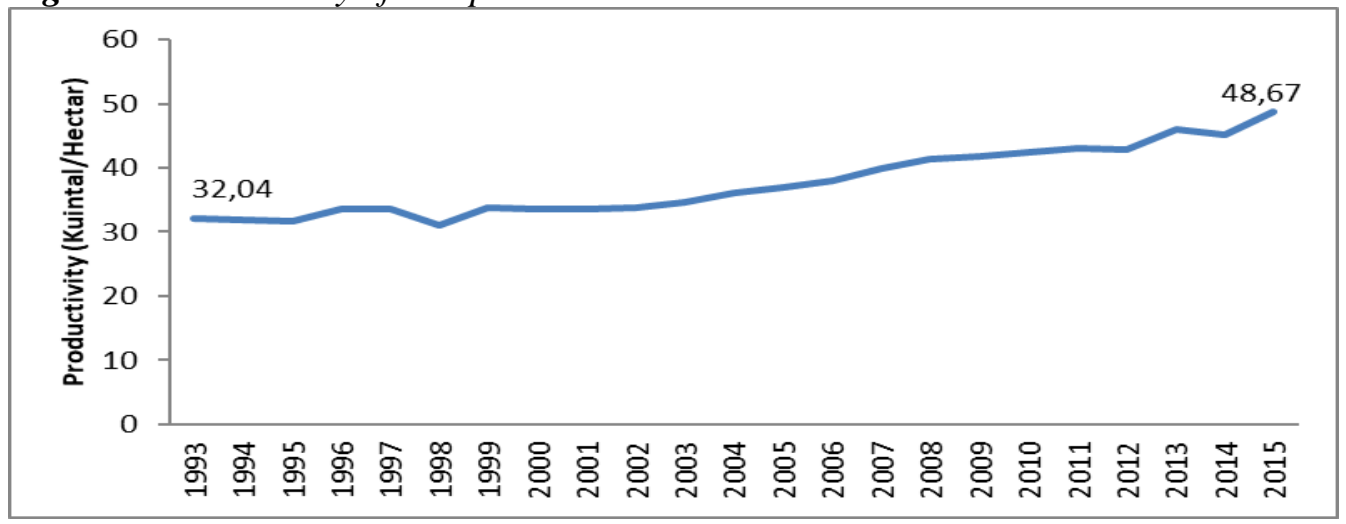

Source: Central Bureau of Statistics (BPS), South Sumatera in figures, 2016

The trend of rice production in Figure 3 shows positive trend and variations. There is a positive value if seen by the average production, even though Ogan Komering Ilir (OKI) has lower average compared with other regencies. The average growth of rice production in OKI is $2.34 \%$, Ogan Komering Ulu Timur (OKUT) is $6.44 \%$ and Banyuasin is $8.58 \%$.

Figure 3. Rice Production Trend in OKI, OKUT and Banyuasin 2005-2015

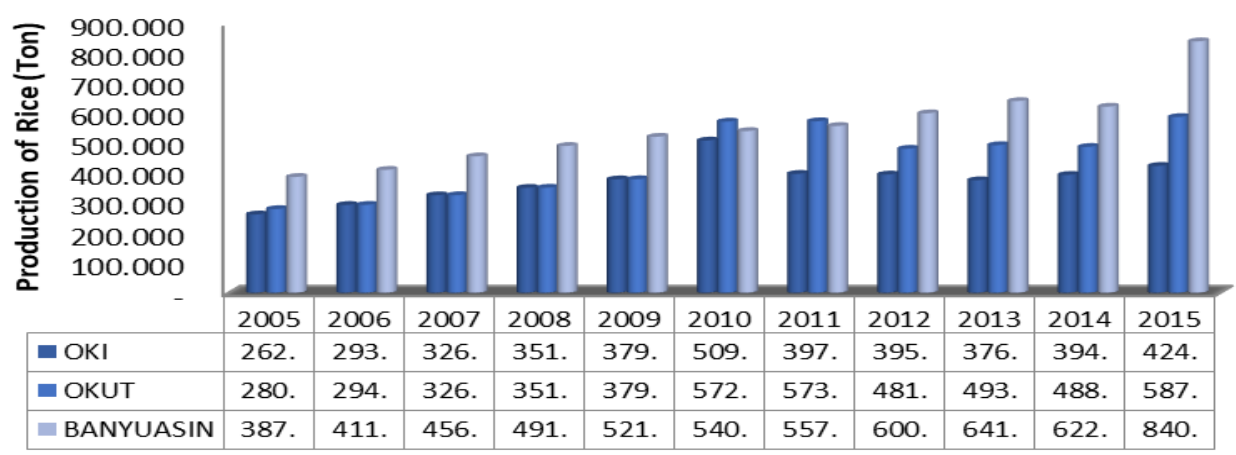

Source: Central Bureau of Statistics (BPS), South Sumatera in figures, 2016

The results from the observation shows that rice production in OKI has a decreasing trend which can be seen from 2011-2013. This may be caused because more and more people are converting their land into plantations. The development of rice production in the three areas can affect rice production at province level as these 
areas are the biggest rice contributors in South Sumatera with the contribution reaching $65.22 \%$ of the total production at the province level.

\subsection{Contribution of Rice Production}

Regional contributions, such as OKI, OKU Timur, and Banyuasin in rice production at the Provincial level show a considerable development even though there is a fluctuative growth. From these three areas, the region that has the biggest contribution is Banyuasin with the average growth of $26.24 \%$.

Table 2. Contribution of Three Biggest Rice Production Area in South Sumatera

\begin{tabular}{lcccc}
\hline \multirow{2}{*}{ Year } & \multicolumn{2}{c}{ Contribution Area of Rice Production } & \multirow{2}{*}{ Total } \\
\cline { 2 - 3 } & OKI & OKUT & Banyuasin & \\
\hline 2005 & 17,94 & 19,17 & 26,53 & 63,65 \\
2006 & 18,95 & 18,96 & 26,51 & 64,42 \\
2007 & 18,95 & 18,96 & 26,51 & 64,42 \\
2008 & 18,95 & 18,96 & 26,51 & 64,42 \\
2009 & 18,95 & 18,96 & 26,05 & 63,96 \\
2010 & 24,62 & 27,69 & 26,16 & 78,47 \\
2011 & 18,11 & 26,11 & 25,39 & 69,61 \\
2012 & 18,90 & 23,01 & 28,68 & 70,59 \\
2013 & 16,11 & 21,13 & 27,45 & 64,69 \\
2014 & 16,54 & 20,47 & 26,11 & 63,11 \\
2015 & 11,48 & 15,91 & 22,76 & 50,14 \\
\hline Average & $\mathbf{1 8 , 1 4}$ & $\mathbf{2 0 , 8 5}$ & $\mathbf{2 6 , 2 4}$ & $\mathbf{6 5 , 2 2}$ \\
\hline
\end{tabular}

Source: Central Bureau of Statistics (BPS), South Sumatera in figures, 2016

OKU Timur has an average contribution of $20.85 \%$ while OKI contributes $18.14 \%$ on average of the total production of South Sumatera. This might be due to the participation of farmers in increasing rice production. There are other factors that can drive the result of agricultural production such as weather, land structure, fertilizer and drugs in eradicating pests that can disrupt rice production. The development of rice production becomes one of the government's goals in overcoming food insecurity in the regions.

\subsection{Rice Price Development}

The price of rice each year has been increasing even though it is one of the commodities that price needs to be stable. The high price is not due to the high demand but other factors such as the price of other products. 
Figure 4. The price development of unlulled rice at primary and retail level

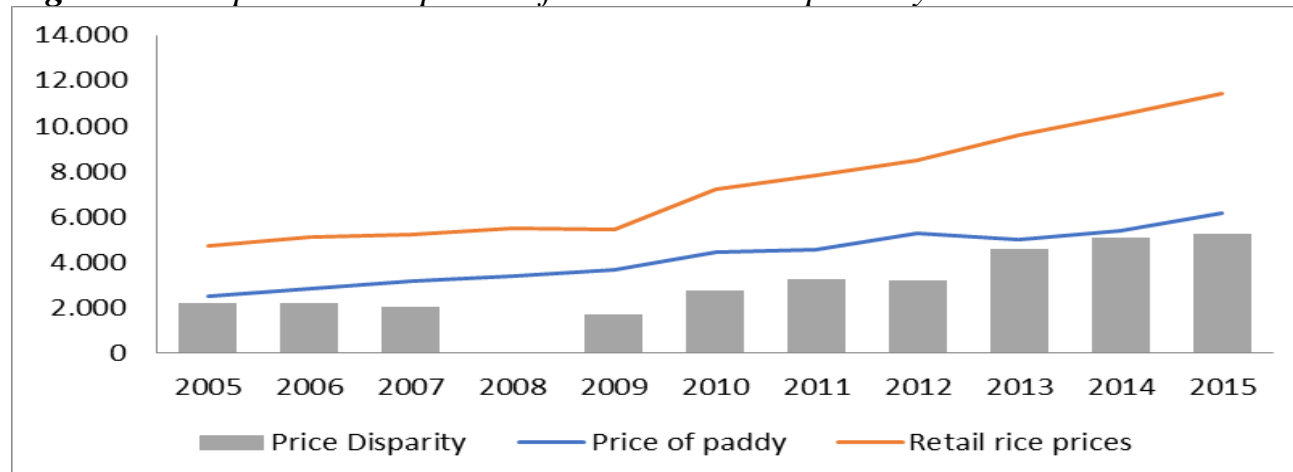

Source: Central Bureau of Statistics (BPS), South Sumatera in figures, 2016

The development of rice has been increasing especially in local areas with significant increase. From Figure 4 above, the price at regency level has increased rapidly along with other price of primary products. Based on the findings, the farmers revealed that the expected government support has been useful in helping them increasing their productivity. These supports consist of auxiliary materials such as fertilizers, superior rice seeds and drugs for pests that can damage rice crops. According to Azwardi et al. (2016) support or subsidy has a profound effect on rice pricing at the village or sub-district level.

Price determination cannot be separated from the price in central market such as Palembang. The selling and buying price in central market stipulates the price at district/city level. There is a strong centre to local market integration that the rice pricing depends on the centre-market such as Palembang.

\subsection{Market Integration}

To determine the existence of market integration in South Sumatera, Monkel and Petzel criteria are used. Based on these criteria, it can be said that the rice market in South Sumatera is integrated (there is an association between the price of rice at the levels of consumer and producer at the regional market). This is affected by the price at consumer level in central market such as Palembang, which is the capital city of South Sumatera.

Table 3. Regression Results in of Three Models Banyuasin, OKUT and OKI

\begin{tabular}{lccc}
\hline Variable & Model 1 & Model 2 & Model 3 \\
\hline Intercept (C) & 10.24544 & 19.62681 & 10.75190 \\
& $(6.460084)$ & $(31.71550)$ & $(6.995590)$ \\
Price of Rice BYS & $0.432852^{* * *}$ & & \\
Price of Rice OKUT & $(0.082477)$ & & \\
& & $0.449087 * * *$ & \\
& & $(0.041611)$ &
\end{tabular}


Price of Rice OKI

$0.529790 * * *$

$(0.091029)$

$\mathbf{R}^{2}$

0.753718

0.928273

0.790074

$\mathbf{N}$

11

11

11

Dependent variable: Producer Price of Rice (Pf)

Independent variable: Consumer Price of Rice $(\mathrm{Pr})$

Information: BYS (Banyuasin), OKUT (Ogan Komering Ulu Timur), OKI (Ogan Komering

Ilir)

$* * *$ Indicates statistical significance at $\alpha=0.01$.

Source: Result of field study (proccessed)

Table 3 shows the results of three models used in this study. The first model shows that the price of rice at consumer level in local market significantly affects the price at producer level in Banyuasin. Similarly, the second model also shows the significant effect of price at consumer level at local market on the price at producer level in OKU Timur. This indicates that there is a market integration in both markets.

Furthermore, the third model is also showing similar result indicating that consumer price at local market in OKI affects the producer price in OKI. The significant effect of price at centre market (Palembang) on the price at local market (OKI) indicates there is market integration in the two markets. Statistically, the consumer price in the three areas will affect the rice price in the producer markets in each area. This indicates that there is market integration in consumer and producer rice market at each local market in Banyuasin, OKU Timur and OKI. The occurrence of such market integration is due to the relatively smooth information on the level of price at the market and adequate mobility of human and products between the two markets. The relatively good mobility between markets is supported by good transportation facilities and infrastructure. If there is a price difference between the two markets then there is a tendency for rice to be sold to a market offering relatively higher price.

\subsection{Index of Market Connection}

This index is developed by Timmer (1987) to measure long-term and short-term market integration. This method concludes that market structure consist of one primary market and several secondary markets. Primary market controls price determination while secondary markets respond the condition of primary market.

Table 4. Regression Results and Index of Market Connection

\begin{tabular}{|c|c|c|c|c|c|}
\hline \multirow{2}{*}{ Market } & \multicolumn{3}{|c|}{$2005-2015^{a}$} & \multirow{2}{*}{ F-test ${ }^{b}$} & \multirow{2}{*}{ IMC } \\
\hline & $\beta_{1}$ & $\beta_{2}$ & $\beta_{3}$ & & \\
\hline Banyuasin & $\begin{array}{c}0.008157 \\
(0.392476)\end{array}$ & $\begin{array}{c}0.667712 * * * \\
(0.134771)\end{array}$ & $\begin{array}{c}0.800977 * * * \\
(0.315729)\end{array}$ & 72.46420 & 0,010184 \\
\hline OKU Timur & $\begin{array}{c}0.183283 \\
(0.416876)\end{array}$ & $\begin{array}{c}0.724435 * * * \\
(0.169098)\end{array}$ & $\begin{array}{c}0.656938 * * * \\
(0.331656)\end{array}$ & 68.24597 & 0,278996 \\
\hline
\end{tabular}




$\begin{array}{lccccc}0.180465 & 0.628853^{* * *} & 0.966656^{* * *} * & 86.76183 & 0,186690\end{array}$

${ }^{a}$ Both segmentation and strong short-run integration rejected for all at 0.01 level

${ }^{b}$ F-test for segmentation (hypothesis 1).

**** significant at 0.05 level

Table 4 shows the results of regression and the calculation of IMC for the three sample areas. It can be seen that, the regression coefficient $\left(\beta_{1}\right)$ of lagged price at the farmers' market level is 0.008157, 0.183283, and 0.180465 for Banyuasin, OKU Timur, Ogan Komering Ilir (OKI) respectively. Meanwhile, the regression coefficient $\left(\beta_{2}\right)$ of the difference of price and lagged price at the consumer level and lag price for the three areas are $0.667712,0.724435$ and 0.628853 . As for the regression coefficient $\left(\beta_{3}\right)$ of lagged basic price at consumer level, the values for Banyuasin, OKU Timur and OKI are 0.800977, 0.656938, 0.966656, respectively. Therefore, by using the three coefficients, IMC calculated of these areas are as follows, 0.010184 (Banyuasin), 0.278996 (OKU Timur) and 0.186690 (OKI). The values of the IMC of all areas are less than 1 indicating that the two markets (primary and secondary market) have short-term vertical integration. Furthermore, in determining the long-term market integration, the coefficient value of the difference of current price $(\mathrm{t})$ and lagged price $(\mathrm{t}-1)$ at the consumer level is used. The value of $\left(\beta_{2}\right)$ at the two level of rice market in Banyuasin is 0.667712 and 0.724435 as well as 0.628853 for OKU Timur and OKI, correspondingly. These coefficient values are less than 1 indicating that these markets (primary and secondary) are not integrated in the long-term.

\section{Conclusion}

The result of the analysis and discussion above concludes that there is market integration of rice price at consumer and producer level in each region (Banyuasin, OKU Timur, OKI) in South Sumatera. The occurrence of such market integration is due to the relatively smooth information on the level of price at the market and adequate mobility of human and products between the two markets. The relatively good mobility between markets is supported by good transportation facilities and infrastructure. If there is a price difference between the two markets then there is a tendency for rice to be sold to a market offering relatively higher price.

In addition, the Index of Market Connection (IMC) coefficients of the three regions of Banyuasin, OKU Timur and OKI indicate that producer rice prices in the primary market are linked to the price of rice in the secondary market (consumer level). Each region has IMC value less than 1, which means, both markets have vertical integration in the short run. Other findings also show that there is a high price disparity between the two markets influenced by the long distribution chain from producer to consumer (Syahza, 2003). The occurrence of this disparity will cause the high cost of marketing margin distribution, so there is a part that must be issued as a profit trader (Adam et al., 2017). Although in general, farmers are not involved in 
the product marketing chain, so the added value of processing and trading of agricultural products is only enjoyed by traders. This tends to minimize the share that the farmer receives and increases the cost to be paid by the consumer.

\section{References:}

Adam, M., Marwa, T., Azwardi, A., Thamrin, K.H., Bashir, A.2017). Analysis of Rice Distribution in South Sumatera, Indonesia. International Journal of Economics and Financial Issues, 7(3), 166-171.

Adeoye, I.B., Dontsop-Nguezet, P.M., Badmus, M.A. and Amao, I.O. 2011. Price Transmission and Market Integration of Banana and Plantain in Oyo State, Nigeria. Journal of Agricultural and Biological Science. 6(5), 18-24.

Ajjan, N., Shajeena, M.H. and Raveendaran, N. 2013. A study on Integration of Chick Pea Markets in India. Indian Journal of Agricultural Marketing, 27(1), 132-141.

Akintunde, O.K., Yusuf, S.A., Bolarinwa, A.O. and Ibe, R.B. 2012. Price Formation and Transmission of Staple Food Stuffs in Osun State, Nigeria. Journal of Agricultural and Biological Science, 7(9), 699-708.

Agung, I.D.G., Daryanto, J. 2017. Analysis of Rice Market Integration in Bali Province. Journal of Agribusiness and Agro, 6(1), 115-121.

Arifin, B., Suparmin., Sugiyono. 2006. Analysis of Indonesian Rice Trading Policy. Journal of Socio-Economics, 6 (2).

Asmarantaka, R.W. 2009. Marketing of Agricultural Products: The Potpourri of Agribusiness Series Marketing. Bogor, IPB Press.

Azwardi, A., Bashir, A., Adam, M., Marwa, T. 2016. The Effect of Subsidy Policy on Food Security of Rice in Indonesia. International Journal of Applied Business and Economic Research, 14(13), 9009-9022.

Bondarenko, A.V., Parkhomenko, V.T., Erokhina, B.T., Guzenko, V.N. 2017. Marketing and Logistic Instrumentarium of Activation of Inter-Country Cooperation of Russia and Solving the Issue of Import Substitution. European Research Studies Journal, 20(1), 105-116.

Breckova, P. 2016. SMEs Export Activities in the Czech Republic and Export Risk Insuring. European Research Studies Journal, 19(1), 84-92.

Central Bureau of Statistics (BPS) South Sumatera. 2016. South Sumatera in figures.

Chizari, A.H., Sani, M.F., Kalashami, M.K. 2013. Investigating Market Integration and Price Transmission of Different Rice Qualities in Iran. International Journal of Agricultural Management and Development, 3(4), 219-225.

Edi, Sirojuzilam, Rahmanta. 2014. Analysis of Integration and Volatility of ASEAN Regional Rice Price on Indonesian Rice Market. Journal of Economists, 17(2), 77-91.

Emokaro, C.O., Ayantoyinbo, A.A. 2014. Analysis of Market Integration and Price Variation in Rice Marketing in Osun State, Nigeria. American Journal of Experimental Agriculture, 4(5), 601-618.

Epifanova, T., Romanenko, N., Mosienko, T., Skvortsova, T. and Kupchinskiy, A. 2015. Modernization of Institutional Environment of Entrepreneurship in Russia for Development of Innovation Initiative in Small Business Structures. European Research Studies Journal, 18(3), 137-148.

Fadhla, B.A., Nugroho, Mustajab, M.M. 2008. Integration of Food Commodity Market (Rice, Peanut and Soybean) in Nanggroe Aceh Darussalam Province. Journal Agritek, 16(9), 41-62. 
Goletti, F., Ahmed, R., Farid, N. 1995. Structural Determinants of Market Integration: The Case of Rice Markets in Bangladesh. The Developing Economies, 33(2), 196-198.

Heytens, P.J. 1986. Testing Market Integration. Food Research Institute Studies, 20(1), 2541.

Kariuki, M.B.J. 2011. Analysis of Market Performance: A Case of 'OMENA' Fish in selected outlets in Kenya. (M.Sc. Thesis), Egerton University.

Kovalenko, E.G., Yakimova, Y.O., Avtaykina V.E. and Zaytseva, O.O. 2016. Problems and Mechanisms of Sustainable Development of Rural Areas (at the example of the Republic of Mordovia). European Research Studies Journal, 19(3) Part A, 110-122.

Leonard, J.K., Cheung, Sui-Wai. 2011. The Price of Rice Market Integration in EighteenthCentury China. International Journal of Asian Studies, 8(2), 226-228.

Limbong, W.H. 1999. Marketing System of Agricultural Food Commodities in some Provence of Indonesia. Journal of Agriculture and Resource Socio-Economics, 12(1), 50-72.

Meyer, J., Cramon-Taubadel, S.V. 2004. Asymmetric Price Transmission: A Survey. Journal of Agricultural Economics, 55(3), 581-611.

Monke, E., Petzel, T. 1984. Market Integration: An Application to International Trade in Cotton. American Journal of Agricultural Economics, 66(4), 481-487.

Nuraeni, D., Anindita, R. 2016. Analysis of Price Variation and Integration of Onion Market in West Java. Journal of Habitat, 26(3), 163-172.

Oladapo, M.O., Momoh, S. 2007. An Analysis of Price Transmission for Selected Agricultural Commodities in Ogun State, Nigeria. Nigerian Journal of Horticultural Science, 12(3), 99-105.

Palaskas, T.B., Harriss, B. 1991. Testing Market Integration: New Approaches with Case Material from the West Bengal Food Economy. The Journal of Development Studies, 30(1), 1-57.

Paul, R.K., Saxena, R., Chaurasia, S., Zeeshan, Rana, S. 2015. Examining Export Volatility, Structural Breaks in Price Volatility and Linkages between Domestic and Export Prices of Onion in India. Agricultural Economics Research Review, 28(1), 101-116.

Sanogo, I., Maliki, M. 2010. Rice market integration and food security in Nepal: The role of cross- border trade with India. Food Policy, 35(4), 312-322.

Syahza, A. 2003. New Paradigm: Marketing of Agricultural Products, Agribusiness based. Journal of Economics, 8(1), 1-11.

Taufiq. 2004. Agribusiness Economics. Palembang, Faculty of Economics, Sriwijaya University.

Taufiq. 2001. The Respond of Rice Market Agents Toward the Changes of Price and Non Price Variables in South Sumatra. Ph.D diss., Bandung, Padjadjaran University.

Timmer, C.P. 1987. A Model of Marketing Margins in Indonesia. Food Research Studies, 13(2), 145-67.

Vavra, P., Goodwin, K.B. 2005. Analysis of Price Transmission Along Food Chain. OECD Food, Agriculture and Fisheries Working Papers, No. 3, OECD Publishing.

Wani, M.H, Paul, R.K, Bazaz, N.H., Manzoor, M. 2015. Market Integration and Price Forcasting of Apple in India. Indian Journal of Agricultural Economics 70(2), 169-181. 